\title{
Monitoring Disease Activity in Systemic Lupus Erythematosus With Single-Molecule Array Digital Enzyme-Linked Immunosorbent Assay Quantification of Serum Interferon-a
}

\author{
Alexis Mathian, ${ }^{1}$ (D) Suzanne Mouries-Martin, ${ }^{2}$ Karim Dorgham, ${ }^{3}$ (D) Hervé Devilliers, ${ }^{4}$ Laura Barnabei, ${ }^{5}$ \\ Elyès Ben Salah, ${ }^{3}$ Fleur Cohen-Aubart, ${ }^{1}$ (D) Laura Garrido Castillo, Julien Haroche, ${ }^{1}$ Miguel Hie, ${ }^{6}$ \\ Marc Pineton de Chambrun, ${ }^{6}$ Makoto Miyara, ${ }^{3}$ Delphine Sterlin, ${ }^{3}$ Micheline Pha, ${ }^{6}$ Du Lê Thi Huong, ${ }^{6}$ \\ Frédéric Rieux-Laucat, ${ }^{5}$ Flore Rozenberg, ${ }^{7}$ Guy Gorochov, ${ }^{3}$ (D) and Zahir Amoura ${ }^{1}$
}

Objective. No simple or standardized assay is available to quantify interferon-a (IFNa) in routine clinical practice. Single-molecule array (Simoa) digital enzyme-linked immunosorbent assay (ELISA) technology enables direct IFNa quantification at attomolar (femtogram per milliliter [fg/ml]) concentrations. This study was undertaken to assess IFNa digital ELISA diagnostic performances to monitor systemic lupus erythematosus (SLE) activity.

Methods. IFNa concentrations in serum samples from 150 consecutive SLE patients in a cross-sectional study were determined with digital ELISA and a functional biologic activity assay (bioassay). According to their Safety of Estrogens in Lupus Erythematosus National Assessment version of the Systemic Lupus Erythematosus Disease Activity Index (SLEDAl) flare composite scores, patients were divided into groups with inactive SLE (SLEDAl score of $<4$ or clinical SLEDAl score of 0 ) or active SLE (SLEDAI score of $\geq 4$ or clinical SLEDAl score of $>0$ ), and into groups with no flare or mild/moderate flare or severe flare.

Results. Based on serum samples from healthy blood donors, the abnormal serum IFNa level threshold value was $136 \mathrm{fg} / \mathrm{ml}$. Next, using receiver operating characteristic curves for an SLE patient series that was widely heterogeneous in terms of disease activity and organ involvement, the threshold IFNa value associated with active disease was determined to be $266 \mathrm{fg} / \mathrm{ml}$. The digital ELISA-assessed serum IFNa level was a better biomarker of disease activity than the Farr assay because its specificity, likelihood ratio for positive results, and positive predictive value better discerned active SLE or flare from inactive disease. The digital ELISA was more sensitive than the bioassay for detecting low-abnormal serum IFNa concentrations and identifying patients with low disease activity.

Conclusion. Direct serum IFNa determination with a highly sensitive assay might improve monitoring of clinical SLE activity and selection of the best candidates for anti-IFNa treatment.

\section{INTRODUCTION}

Systemic lupus erythematosus (SLE) is a chronic autoimmune disease of unknown etiology characterized by the presence

Supported by the AP-HP (Centre d'Investigations Biomédicales PitiéSalpêtrière), INSERM, Sorbonne Université, the French Arthritis Foundation, the Société National Française de Médecine Interne, and the Fondation pour la Recherche Médicale. Ms Barnebai is a fellow of the ImaginePhD international program supported by the Fondation Bettencourt Schueller.

${ }^{1}$ Alexis Mathian, MD, PhD, Fleur Cohen-Aubart, MD, PhD, Julien Haroche, MD, PhD, Zahir Amoura, MD, MSc: Sorbonne Université, Assistance PubliqueHôpitaux de Paris, Groupement Hospitalier Pitié-Salpêtrière, French National Referral Center for Systemic Lupus Erythematosus, Antiphospholipid Antibody Syndrome and Other Autoimmune Disorders, Service de Médecine Interne 2, Institut E3M, INSERM UMRS, Centre d'Immunologie et des Maladies Infectieuses (CIMI-Paris), Paris, France; ${ }^{2}$ Suzanne MouriesMartin, MD, MSc: Centre Hospitalier Universitaire de Dijon, Hôpital FrançoisMitterrand, service de médecine interne et maladies systémiques (médecine of antinuclear autoantibodies and inflammation in a wide spectrum of organs $(1,2)$. The survival of SLE patients has plateaued since the middle 1990s (3). To date, anti-double-stranded DNA (anti-dsDNA) antibody titration, best achieved with the standard

interne 2), Dijon, France; ${ }^{3}$ Karim Dorgham, PhD, Elyès Ben Salah, PharmD, Laura Garrido Castillo, MSc, Makoto Miyara, MD, PhD, Delphine Sterlin, PharmD, PhD, Guy Gorochov, MD, PhD: Sorbonne Université, INSERM UMRS, Centre d'Immunologie et des Maladies Infectieuses (CIMI-Paris), Assistance Publique-Hôpitaux de Paris, Groupement Hospitalier Pitié-Salpêtrière, Paris, France; ${ }^{4}$ Hervé Devilliers, MD, PhD: Centre Hospitalier Universitaire de Dijon, Hôpital François-Mitterrand, service de médecine interne et maladies systémiques (médecine interne 2) and Centre d'Investigation Clinique, INSERM CIC 1432, Dijon, France; '5aura Barnabei, MSc, Frédéric Rieux-Laucat, PhD: Laboratory of Immunogenetics of Pediatric Autoimmune Diseases, INSERM UMR-Institut Imagine, Sorbonne Paris Cité, Paris, France; ${ }^{6}$ Miguel Hie, MD, MSc, Marc Pineton de Chambrun, MD, MSc, Micheline Pha, MD, MSc, Du Lê Thi Huong, MD, PhD: Assistance Publique-Hôpitaux de Paris, Groupement Hospitalier Pitié-Salpêtrière, French National Referral Center 
Farr assay, has been used to monitor global disease activity and SLE renal involvement (4-7). However, because associations with disease characteristics are at best modest, clinicians and researchers still lack reliable biomarkers of SLE activity (4-7). At present, many authors consider the dysregulation of interferons (IFNs) to be a central cause of the immunologic abnormalities observed in SLE (8-14).

Early studies showed elevated serum IFNa levels in SLE patients to be associated with disease activity and severity (15-17). More recently, transcriptome analysis using microarray technology revealed up-regulation of numerous IFNstimulated genes (ISGs) in the peripheral blood mononuclear cells of patients with SLE, constituting an overall "IFN signature" $(18,19)$. That signature is found in almost all pediatric patients and $50-80 \%$ of adults with SLE (20). Thus, the close association between IFNa overexpression and SLE activity suggests that monitoring this cytokine might help physicians better evaluate disease activity (21-25). Knowing the IFNa concentration might also help select the best candidates for anti-IFNa treatment $(26,27)$. Unfortunately, no reliable, simple, or standardized assays to quantify IFNa in routine clinical practice are available; notably, enzyme-linked immunosorbent assays (ELISAs) to detect IFNa in human sera have been hindered by low sensitivity and low specificity (28), and assays based on detecting IFNa biologic activity are difficult to standardize (15-17). Alternatively, quantification of the expression of different ISGs as "IFN scores" can be used as a surrogate to monitor IFN activity in SLE (29-31). Not surprisingly, IFN scores have been associated with SLE activity (29,32-34). However, the low availability and high complexity of transcriptome-microarray technology means that the IFN scores, as well, are not standardized and cannot be used in routine practice.

The new single-molecule array (Simoa) assay, also called digital ELISA, based on counting individual enzyme-labeled immunocomplexes of proteins captured on beads in single-molecule arrays, enables direct IFNa quantification at attomolar (femtogram per milliliter $\left[\mathrm{fg} / \mathrm{ml}\right.$ or $5 \times 10^{-15}$ moles $/ \mathrm{ml}$ ) concentrations (35-37), corresponding to a 5,000-fold increased sensitivity over commercial ELISAs. We hypothesized that serum IFNa levels determined with this new standardized assay would represent a better biomarker of SLE activity than the Farr assay. Therefore, the primary objective of this study was to characterize the relationship between digital ELISA-determined serum IFNa concentrations and clinically assessed SLE activity. We also compared

for Systemic Lupus Erythematosus, Antiphospholipid Antibody Syndrome and Other Autoimmune Disorders, Service de Médecine Interne 2, Institut E3M, Paris, France; ${ }^{7}$ Flore Rozenberg, MD, PhD: Sorbonne Paris Cité, Assistance Publique-Hôpitaux de Paris, Hôpital Cochin, Service de Virologie, Paris, France.

Drs. Mathian, Mouries-Martin, and Dorgham contributed equally to this work. Drs. Gorochov and Amoura contributed equally to this work. that assay to a functional sensitive biologic assay (bioassay), based on IFNa antiviral properties, that has been used routinely in our institution for 30 years (38-40).

\section{PATIENTS AND METHODS}

Study design, patients, and controls. Serum samples were obtained from 150 consecutive patients (139 women, 11 men) diagnosed as having SLE according to the 1997 updated American College of Rheumatology criteria for SLE classification (41). SLE patients were referred to our National Referral Center for SLE. SLE clinical characteristics, the Safety of Estrogens in Lupus Erythematosus National Assessment (SELENA) version of the Systemic Lupus Erythematosus Disease Activity Index (SLEDAI) (42-44), and the therapeutic regimen were recorded on the day blood was drawn (day 0). The class of lupus nephritis, according to the International Society of Nephrology/Renal Pathology Society 2003 classification (45), was recorded, and the serum sample was obtained within 3 days before or after the renal biopsy. Routine testing to determine anti-dsDNA antibody titers using the Farr assay (cutoff value $9.0 \mathrm{lU} / \mathrm{ml}$ ) (Trinity Biotech) and anti-RNP antibody levels (anti-Sm, anti-SSA/Ro60, anti-Ro 52/TRIM21, and anti-SSB) (Luminex FIDIS; Theradiag) was conducted, and laboratory analyses to determine C3 and C4 levels (Optilite; The Binding Site), complete blood cell counts, serum creatinine levels, and presence of proteinuria and hematuria were performed.

According to their SELENA-SLEDAI scores, patients were divided into groups of inactive SLE (SLEDAI score $<4 ; n=68$ ) or active SLE (SLEDAI score $\geq 4 ; n=82$ ). The presence of a severe or mild/moderate lupus flare was recorded according to the SELENA-SLEDAI flare instrument (see Supplementary Methods, available on the Arthritis \& Rheumatology web site at http:// onlinelibrary.wiley.com/doi/10.1002/art.40792/abstract) $(43,44)$. For logistic regression analyses, the domains of activity were assigned by the SELENA-SLEDAI scores in those domains. Serum samples from 68 age- and sex-matched healthy donors (Établissement Français du Sang, Île-de-France, Pitié-Salpêtrière Hospital) were collected during the same time period.

The primary objective of the study was to assess the diagnostic performance of the IFNa digital ELISA to monitor SLE activity. The secondary goal was to compare the performances of the digital ELISA and the bioassay. Exclusion criteria were 1) known or suspected infection on day 0 , or 2) increased hydroxychloroquine, prednisone, and/or immunosuppressant dose(s)

No potential conflicts of interest relevant to this article were reported

Address correspondence to Alexis Mathian, MD, PhD, Service de Médecine Interne 2, Institut E3M, Hôpital de la Pitié-Salpêtrière, 47-83, Boulevard de l'Hôpital, 75651 Paris Cedex 13, France. E-mail: alexis.mathian@aphp.fr.

Submitted for publication December 18, 2017; accepted in revised form November 18, 2018. 
during the 4 weeks preceding day 0 . The study was approved by the local ethics committee (no. 30052012), and informed consent was provided by all participants. The research was carried out in compliance with the Helsinki Declaration.

IFNa bioassay. Serum IFNa biologic activity (in IU/ml) was determined by assessing the protection afforded by each patient's serum to cultured Madin-Darby bovine kidney cells infected with vesicular stomatitis virus, as described previously $(38,46-48)$ (see Supplementary Methods, available on the Arthritis \& Rheumatology web site at http://onlinelibrary.wiley.com/doi/10.1002/ art.40792/abstract). Bioassay sensitivity (the lower limit of detection) was $2 \mathrm{IU} / \mathrm{ml}$. Serum IFNa activity in healthy individuals is undetectable at a level of $<2 \mathrm{IU} / \mathrm{ml}(39,49)$.

IFNa digital ELISA. Serum IFNa concentrations (in $\mathrm{fg} / \mathrm{ml}$ ) were determined with an IFNa digital ELISA technology reagent kit (Simoa; Quanterix), which is based on a 3-step protocol using an HD-1 Analyzer (Quanterix) (35) (see Supplementary Methods, available at http://onlinelibrary.wiley.com/doi/10.1002/art.40792/abstract).

Statistical analysis. Qualitative variables are expressed as the number (percentage), and quantitative parameters as the mean \pm SD or median (range), as appropriate. Differences between patient groups were tested with the Mann-Whitney $U$ test or Student's $t$-test for continuous data, and Fisher's exact test or chi-square test for categorical data. Spearman's correlation coefficients were computed for quantitative values. The diagnostic performances of the Farr assay, IFNa digital ELISA, and the bioassay to detect SLE disease activity were investigated by analyzing receiver operating characteristic (ROC) curves, with the SELENA-SLEDAI-assessed clinical activity as the gold standard for those analyses. Because the SELENA-SLEDAI measure includes the Farr assay among the domains scored, we used for this analysis the clinical SELENA-SLEDAI that refers to symptoms, signs, and routine laboratory testing, disregarding the points that can be given for the presence of anti-DNA antibodies and/or low complement levels (50). The areas under the ROC curves (AUCs) to differentiate active versus inactive SLE and an SLE flare versus no flare according to the digital ELISA, bioassay, and Farr assay were compared using a nonparametric approach (51). The optimal thresholds were determined using a compromise among the maximum correct classification rate, the minimum distance to the upper left corner of the ROC curve, the minimum sensitivity - specificity difference, and the Youden index. Sensitivities, specificities, likelihood ratios, positive predictive values, and negative predictive values were calculated. McNemar's test for paired proportions was used to compare sensitivities and specificities. No statistical analyses were performed on likelihood ratios and predictive values.

To identify SLE parameters independently associated with the absence of detectable serum IFNa in patients with active disease, variables significantly associated with the falsenegative rate in bivariable analyses were entered into a multivariable logistic regression model with stepwise selection of variables $(P=0.30$ for entry and $P=0.10$ for exit). Alternatively, to identify SLE parameters independently associated with bioassay- or digital ELISA-detected abnormal IFNa levels, univariable and multivariable logistic regression analyses using backward stepwise variable elimination were performed (with the variable exit threshold set at $P>0.10$ ). All potential explanatory variables included in the multivariable analyses were subjected to collinearity analysis with a correlation matrix. None of these variables were associated with each other. Model goodnessof-fit was assessed with the determination coefficient $\left(R^{2}\right)$. All tests were 2 -sided, and $P$ values less than 0.05 were considered significant. Statistical analyses were performed using GraphPad Prism (version 5.0), IBM SPSS Statistics (version 22.0), and SAS 9.4 software.

\section{RESULTS}

Patient characteristics. The baseline characteristics of the patients are described in Table 1. Approximately half of the patients had SELENA-SLEDAI-defined active SLE (score 24) or a SELENA-defined flare. Immunosuppressant therapy was mycophenolate mofetil for 18 patients, methotrexate for 13 patients, and azathioprine for 6 patients.

Serum IFNa concentrations in SLE patients. Digital ELISA-determined serum IFNa concentrations in patients with active SLE (median 1,396 fg/ml [range 0-53,000]) were significantly higher than those in patients with inactive SLE (median 14 $\mathrm{fg} / \mathrm{ml}$ [range 0-4,328]) $(P<0.0001)$ and healthy controls (median 0 fg/ml [range 0-269]) $(P<0.0001)$. Concentrations also differed significantly between patients with inactive SLE and healthy controls $(P<0.0001)$ (Figure 1).

The IFNa digital ELISA positivity threshold was $136 \mathrm{fg} / \mathrm{ml}$, which is 3 SD above the mean serum IFNa concentration calculated from the serum samples from the 68 healthy blood donors. Using that cutoff value, the digital ELISA was able to detect abnormal serum IFNa concentrations (>136 fg/ml) in 78 SLE patients (52\%).

Bioassay-determined serum IFNa levels were significantly higher in patients with active SLE (median $5 \mathrm{IU} / \mathrm{ml}$ [range 0-200]) than those with inactive disease (median $0 \mathrm{IU} / \mathrm{ml}$ [range 0-12]) $(P<0.0001)$ (Figure 1). The bioassay was able to detect abnormal serum IFNa levels ( $\geq 2 \mathrm{lU} / \mathrm{ml}$ ) in 56 SLE patients (37\%).

Sensitivity of digital ELISA versus the bioassay to detect abnormal serum IFNa levels. Although the digital ELISA- and bioassay-determined serum IFNa levels were significantly correlated (Spearman's rank $r=0.77$ [95\% confidence 
Table 1. Baseline characteristics and disease parameters in SLE patients $(n=150)^{*}$

\begin{tabular}{lc}
\hline Women & $139(92.7)$ \\
\hline Age, mean \pm SD years & $36.2 \pm 12.5$ \\
\hline Disease duration, mean \pm SD years & $9.8 \pm 9.1$ \\
\hline SELENA-SLEDAI score, median (range) & $4(0-36)$ \\
\hline SELENA-SLEDAl score $\geq 4$ & $82(54.7)$ \\
\hline Mild/moderate flare $†$ & $21(14)$ \\
\hline Severe flare $†$ & $53(35.3)$ \\
\hline Fever & $31(20.7)$ \\
\hline Weight loss or anorexia & $18(12)$ \\
\hline Lymphadenopathy & $21(14)$ \\
\hline Active cutaneous lupus & $37(24.7)$ \\
\hline Active lupus serositis & $17(11.3)$ \\
\hline Active lupus arthritis & $44(29.3)$ \\
\hline Active lupus nephropathy & $20(13.3)$ \\
\hline Active neuropsychiatric lupus & $6(4)$ \\
\hline Hydroxychloroquine use & $124(82.7)$ \\
\hline Prednisone use & $90(60)$ \\
\hline Prednisone $\geq 10$ mg/day & $38(25.3)$ \\
\hline Immunosuppressive agent useł & $37(24.7)$ \\
\hline Positive Farr assay & $87(58)$ \\
\hline Positive for anti-RNP antibodies & $53(35.3)$ \\
\hline Positive for anti-Sm antibodies & $28(18.7)$ \\
\hline Positive for anti-Ro/SSA 60 antibodies & $48(32)$ \\
\hline
\end{tabular}

* Except where indicated otherwise, values are the number (\%). SLE = systemic lupus erythematosus; SELENA-SLEDAI = Safety of Estrogens in Lupus Erythematosus National Assessment version of the Systemic Lupus Erythematosus Disease Activity Index.

† Defined using the SELENA flare instrument.

$\ddagger$ Excluding antimalarials and prednisone.

$\S$ Value shown is the number of positive assay results/number of patients assessed (\%).

interval 0.69-0.83]) $(P<0.0001)$, the digital ELISA was able to identify 29 SLE patients with a serum IFNa concentration of $>136$ $\mathrm{fg} / \mathrm{ml}$ (Figure 2) and negative biologic activity (data not shown), thereby indicating the digital ELISA's higher sensitivity than the bioassay to detect abnormal serum IFNa concentrations. We also compared digital ELISA IFNa measurements with the ISG score of samples from 22 SLE patients (see Supplementary Figure 2, available on the Arthritis \& Rheumatology web site at http://onlinelibrary.wiley.com/doi/10.1002/art.40792/abstract). We used an ISG score, described previously by Rice et al, based on quantitative polymerase chain reaction assessment of 6 ISGs $(52,53)$. In this test, the median fold change of the ISGs when compared with the median in healthy controls is used to create an IFN score. Serum IFNa levels were highly positively correlated with the ISG scores $\left(r=0.74, P<10^{-4}\right)$. Only 2 patients showed
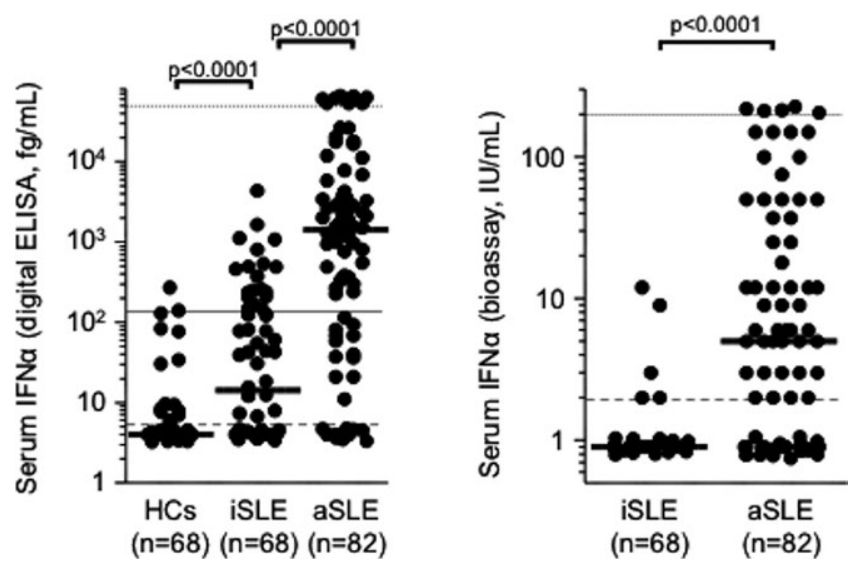

Figure 1. Serum interferon- $\alpha$ (IFNa) concentrations according to systemic lupus erythematosus (SLE) activity assessed with digital enzyme-linked immunosorbent assay (ELISA) (left) or functional bioassay (right). Patients were divided into groups with inactive SLE (iSLE; Systemic Lupus Erythematosus Disease Activity Index [SLEDAI] score of $<4$ ) or active SLE (aSLE; SLEDAl score of $\geq 4$ ). The IFNa digital ELISA positivity threshold (solid lines) was 3 SD above the mean of the 68 serum samples from healthy control $(\mathrm{HC})$ blood donors, i.e., $136 \mathrm{fg} / \mathrm{ml}$. The lower limits (broken lines) and upper limits (dotted lines) of quantification were $5-52,200 \mathrm{fg} / \mathrm{ml}$ for the digital ELISA and 2-200 IU/ml for the functional bioassay. Symbols represent individual subjects; bars show the median. Statistical analyses were conducted using the Mann-Whitney $U$ test.

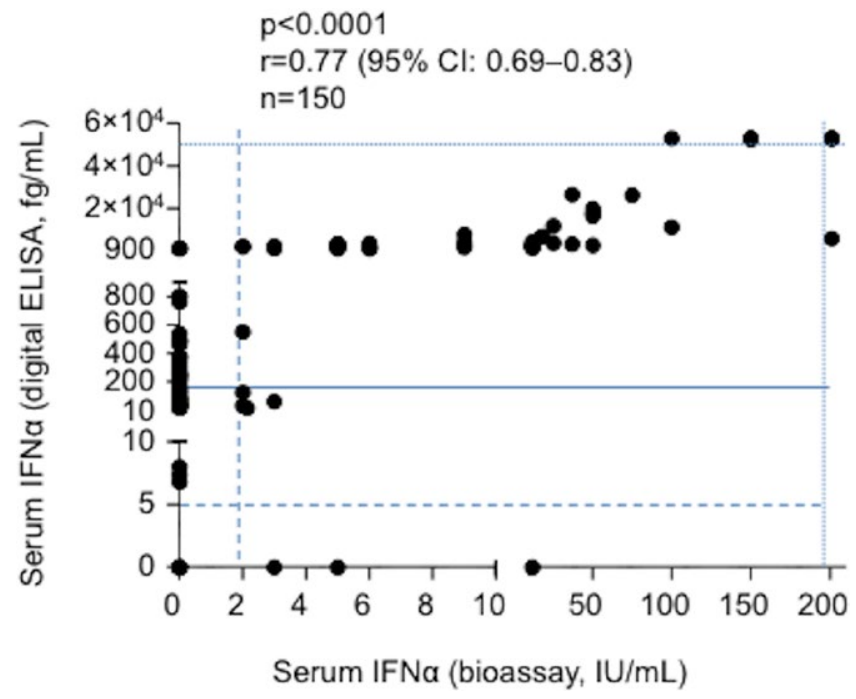

Figure 2. Correlation between the interferon- $\alpha$ (IFNa) digital enzymelinked immunosorbent assay (ELISA)- and bioassay-determined concentrations. The IFNa digital ELISA positivity threshold (solid line), the upper limit of quantification (dotted line), and the lower limit of detection (broken lines) are shown. The IFNa cutoff concentration of 1,130 fg/ml gave the best agreement between the digital ELISA and the bioassay (see Supplementary Figure 1 and Supplementary Table 1, available on the Arthritis \& Rheumatology web site at http://onlinelibrary.wiley. com/doi/10.1002/art.40792/abstract). Symbols represent individual patients. Statistical analyses were conducted using Spearman's rank correlation coefficient. 95\% Cl = 95\% confidence interval. 


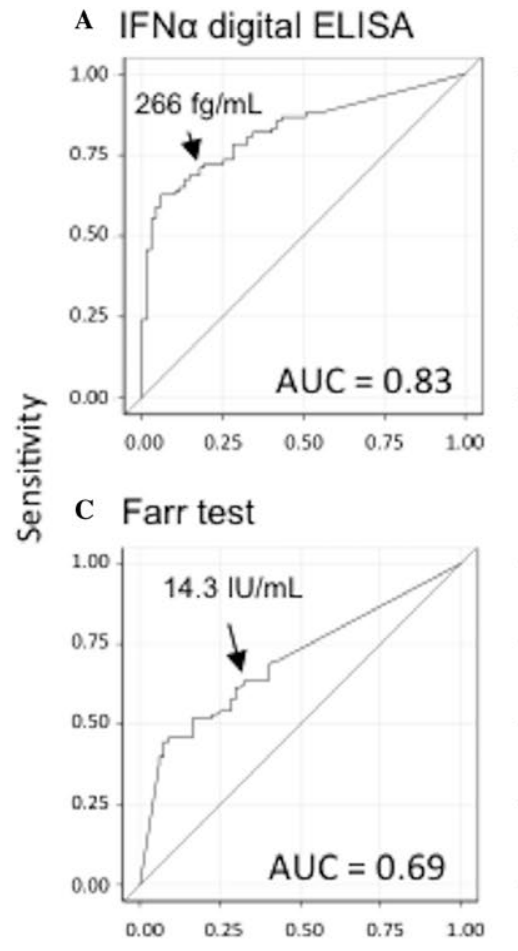

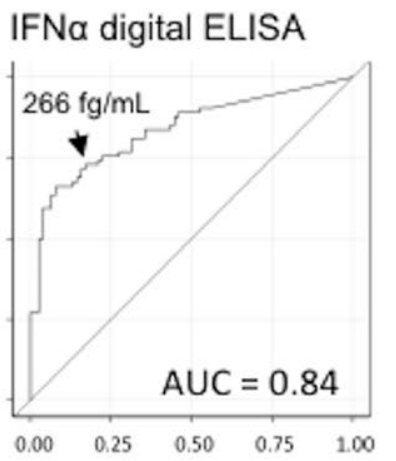

Farr test

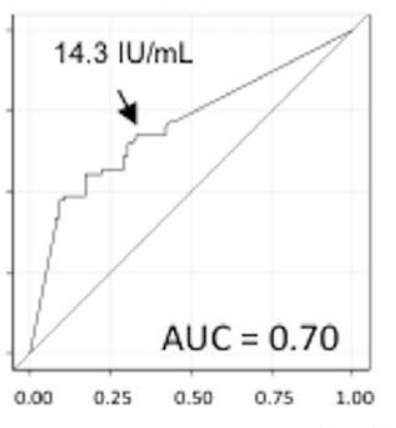

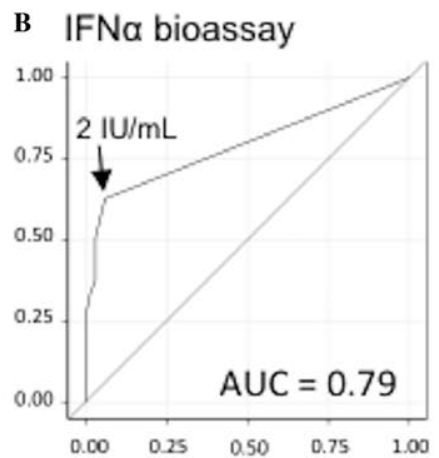

IFN $\alpha$ bioassay

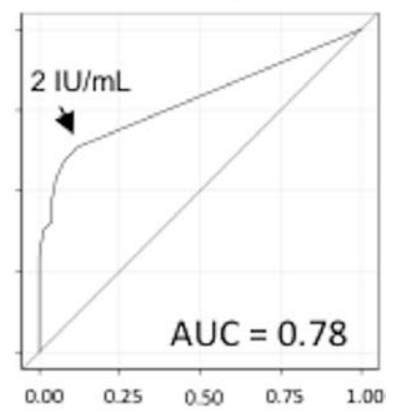

D Comparisons

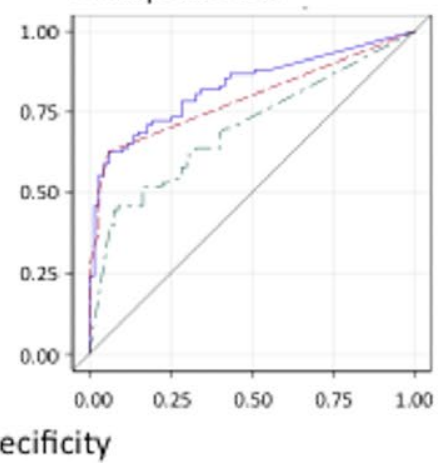

Comparisons

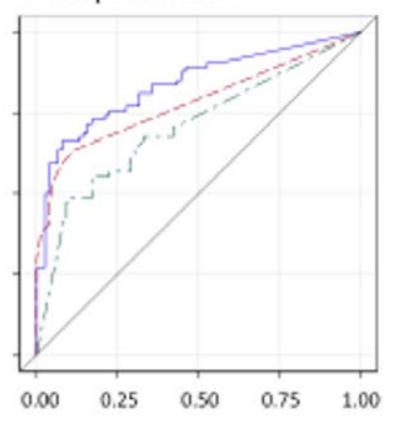

Figure 3. Receiver operating characteristic (ROC) curves of interferon- $\boldsymbol{\alpha}(\mathrm{IFNa})$ concentrations to discern active systemic lupus erythematosus (SLE). A-C, The diagnostic performances of the serum IFNa digital enzyme-linked immunosorbent assay (ELISA) (A), bioassay (B), and Farr assay $(\mathbf{C})$ to detect SLE activity (active versus inactive) were investigated by analyzing ROC curves, with the Safety of Estrogens in Lupus Erythematosus National Assessment (SELENA) version of the Systemic Lupus Erythematosus Disease Activity Index (SLEDAI)-assessed clinical activity score serving as the gold standard. D, The area under each ROC curve (AUC) is given for the digital ELISA (blue), the Farr test (green), and the bioassay (red). The optimal cutoff point represented for each ROC curve was determined using the maximum correct classification rate, the minimum distance to the upper left corner of the curve, the minimum sensitivity - specificity difference, and Youden's index score. In A-D (left), patients were divided into groups with inactive (clinical SLEDAI score of 0) or active SLE (clinical SLEDAI score of >0). In A-D (right), using the SELENA flare identifier, patients were divided into groups with no flare or experiencing a flare.

a positive ISG score and a serum IFNa level below the positivity threshold for the digital ELISA (<136 fg/ml).

Digital ELISA and bioassay diagnostic performances to discriminate active SLE. The ROC AUC for the IFNa digital ELISA to differentiate between active and inactive SLE was 0.83 , better than that of the Farr assay $(0.69 ; P=0.007)$ (Figure 3). The ROC AUC for the IFNa digital ELISA to differentiate between an SLE flare and no flare was 0.84, better than that of the Farr assay (0.70; $P=0.006)$. The ROC AUC for the IFNa bioassay was 0.79 to differentiate between active and inactive SLE $(P=0.04$ versus the Far assay) and 0.78 to differentiate between an SLE flare and no flare ( $P=0.09$ versus the Farr assay).

The optimal thresholds to distinguish between patients with active SLE and those with inactive SLE or between patients with a flare and those without a flare were identical, equal to $266 \mathrm{fg} / \mathrm{ml}$ for the digital ELISA, $2 \mathrm{IU} / \mathrm{ml}$ for the bioassay, and $14.3 \mathrm{IU} / \mathrm{ml}$ for the Farr assay. Using ROC curve-defined thresholds, the IFNa digital ELISA and the IFNa bioassay had significantly better specificity than the Farr assay to differentiate between active and inactive
SLE and between a flare and no flare (Table 2). The IFNa digital ELISA and the IFNa bioassay also had a better likelihood ratio for positive results and positive predictive value to identify active disease and flare than the Farr assay.

\section{Sensitivity of IFNa digital ELISA versus IFNa bioassay} to identify patients with active SLE. The IFNa digital ELISA had significantly better sensitivity than the IFNa bioassay to differentiate between an SLE flare and no flare. Supplementary Table 2 (available on the Arthritis \& Rheumatology web site at http:// onlinelibrary.wiley.com/doi/10.1002/art.40792/abstract) reports positivity rates of the IFNa digital ELISA, bioassay, and Farr test according to SLE activity. The digital ELISA was able to identify a subset of 20 SLE patients with serum IFNa levels between 266 $\mathrm{fg} / \mathrm{ml}$ (the cutoff associated with active SLE) and 1,130 $\mathrm{fg} / \mathrm{ml}$ (the cutoff associated with the best agreement between the digital ELISA and the bioassay). In this subset of patients the median SLEDAI score was slightly, but significantly, higher than that in the subset of patients with serum IFNa levels below normal (4 versus 2; $P=0.01$ ) (see Supplementary Figure 3, at http://onlinelibrary. 
Table 2. Sensitivity and specificity of the IFNa digital ELISA, bioassay, and Farr assays to detect active SLE or flare*

\begin{tabular}{|c|c|c|c|c|c|c|}
\hline & $\begin{array}{l}\text { Sensitivity, \% } \\
(95 \% \text { Cl) }\end{array}$ & $\begin{array}{l}\text { Specificity, \% } \\
\text { (95\% Cl) }\end{array}$ & PLR & NLR & PPV, \% & NPV, \% \\
\hline \multicolumn{7}{|l|}{ Active SLE† } \\
\hline Digital ELISA & $68.7(57.6-78.4)$ & $85.1(74.3-92.6) \S$ & 4.6 & 0.37 & 85.1 & 68.7 \\
\hline Bioassay 9 & $62.7(51.3-73.0)$ & 94.0 (85.4-98.4)\# & 10.5 & 0.40 & 92.9 & 67.0 \\
\hline Farr assay** & $63.9(52.6-74.1)$ & $67.2(54.6-78.2)$ & 1.9 & 0.54 & 70.7 & 60.0 \\
\hline \multicolumn{7}{|l|}{ SLE flaret† } \\
\hline Digital ELISA & $73.0(61.4-82.7) \ddagger \ddagger$ & $82.9(72.5-90.6) \S$ & 4.3 & 0.32 & 80.6 & 75.9 \\
\hline Bioassay $\mathbf{q}$ & $63.5(51.5-74.4)$ & $88.2(78.7-94.4) \S \S$ & 5.4 & 0.41 & 83.9 & 71.3 \\
\hline Farr assay** & $67.6(55.7-78.0)$ & $67.1(55.4-77.5)$ & 2.0 & 0.48 & 66.7 & 68.0 \\
\hline
\end{tabular}

* No statistical analyses were performed on likelihood ratios and predictive values. IFNa = interferon- $\mathrm{a}$; ELISA $=$ enzyme-linked immunosorbent assay; $95 \% \mathrm{Cl}=95 \%$ confidence interval; PLR = positive likelihood ratio; NLR = negative likelihood ratio; PPV = positive predictive value; NPV = negative predictive value.

† Safety of Estrogens in Lupus Erythematosus National Assessment (SELENA) version of the Systemic Lupus Erythematosus Disease Activity Index (SLEDAI)-defined groups were classified as having inactive systemic lupus erythematosus (SLE; clinical SLEDAI score of 0 ) or active SLE (clinical SLEDAI score of $>0$ ).

$¥$ The chosen positivity threshold for this assay was $266 \mathrm{fg} / \mathrm{ml}$.

$\S P<0.05$ versus Farr assay.

q The chosen positivity threshold for this assay was $2 \mathrm{IU} / \mathrm{ml}$.

$\# P<0.001$ versus Farr assay.

** The chosen positivity threshold for this assay was $14.3 \mathrm{IU} / \mathrm{ml}$.

t† Defined using the SELENA flare instrument.

$\ddagger \ddagger P<0.05$ versus bioassay.

$\S \S P<0.01$ versus Farr assay.

wiley.com/doi/10.1002/art.40792/abstract). The vast majority of the subset of patients with serum IFNa levels of 266-1,130 fg/ $\mathrm{ml}$ (17 of 20) had negative results on the bioassay. Thus, the digital ELISA was more sensitive than the bioassay to detect low-abnormal serum IFNa concentrations and patients with low disease activity.

\section{Characteristics of digital ELISA false-negatives.}

Patients with a digital ELISA false-negative result (active SLE but with a serum IFNa concentration of $<266 \mathrm{fg} / \mathrm{mll}$ ), as compared to patients with a true-positive result (active SLE and a serum IFNa concentration of $\geq 266 \mathrm{fg} / \mathrm{ml}$ ), were more likely to be treated with hydroxychloroquine, have more frequent arthritis without other organ involvement, lower anti-RNP antibody rates, and lower SELENA-SLEDAl activity scores (Table 3).

Patient characteristics associated with abnormal serum IFNa levels. According to multivariable analyses, abnormal digital ELISA-determined IFNa concentrations were significantly associated with SLE-specific fever, active mucocutaneous lupus, active lupus nephritis, and anti-Sm antibodies, but no other anti-RNP antibodies (anti-Ro/SSA 52, anti-Ro/SSA 60, anti-La/ SSB, and anti-RNP) (see Supplementary Table 3, at http://onlinelibrary.wiley.com/doi/10.1002/art.40792/abstract). Similar results were obtained with the bioassay except that abnormal IFNa levels were significantly associated with the presence of anti-RNP antibodies, while anti-Ro/SSA 52, anti-Ro/SSA 60, anti-La/SSB and anti-Sm antibodies were not (see Supplementary Table 4, at http://onlinelibrary.wiley.com/doi/10.1002/art.40792/abstract).

\section{DISCUSSION}

The contribution of IFNa as a biomarker of SLE activity has been limited so far by the absence of a simple and standardized sensitive assay to quantify this cytokine routinely. The new ultrasensitive digital ELISA Simoa technology enabled direct IFNa quantification, with a 5,000-fold increased sensitivity over commercial ELISAs $(35,36)$. Recent findings described by Rodero et al suggested that this assay would enhance our understanding of IFNa biology and potentially improve the diagnosis and stratification of pathologies associated with IFNa dysregulation (37). Based on a large series of SLE patients, we confirmed that routine, highly sensitive IFNa quantification is feasible and of interest for monitoring SLE activity. First, using serum samples from healthy blood donors, we calculated that the threshold for abnormal serum IFNa levels was $136 \mathrm{fg} / \mathrm{ml}$. Next, by studying a series of patients with widely ranging SLE activity and organ involvement, we determined that the threshold associated with active disease in the patients was $266 \mathrm{fg} / \mathrm{ml}$. Finally, according to ROC curve analysis, we demonstrated that the digital ELISAdetermined serum IFNa concentration was a better biomarker of SLE activity than concentrations measured with the Farr assay.

To date, anti-dsDNA antibody titration, better achieved with the Farr assay, has been used to monitor global disease 
Table 3. Baseline characteristics of and SLE features in patients with active disease according to detection of IFNa with digital ELISA* $^{*}$

\begin{tabular}{|c|c|c|c|c|c|}
\hline & $\begin{array}{c}\text { IFNa } \\
\text { detectable, } \\
\text { true-positive } \\
(n=57)\end{array}$ & $\begin{array}{c}\text { IFNa not } \\
\text { detectable, } \\
\text { false-negative } \\
(n=25)\end{array}$ & $P \dagger$ & $P \ddagger$ & OR (95\% CI)‡ \\
\hline Age, mean \pm SD years & $30.1 \pm 9.7$ & $36.1 \pm 12.2$ & 0.021 & NS & - \\
\hline Disease duration, mean \pm SD years & $6.4 \pm 6.3$ & $8.5 \pm 7.4$ & 0.19 & - & - \\
\hline Hydroxychloroquine use & $35(61.4)$ & $24(96)$ & 0.001 & 0.04 & $13.0(1.1-148.3)$ \\
\hline Prednisone use & $42(73.6)$ & $15(60)$ & 0.22 & - & - \\
\hline Immunosuppressive agent use§ & $20(35.1)$ & $8(32)$ & 0.79 & - & - \\
\hline Positive Farr assay & $43(75.4)$ & $17(68)$ & 0.48 & - & - \\
\hline Positive for anti-RNP antibodies & $38(66.7)$ & $5(20)$ & $<0.001$ & 0.008 & $0.2(0.1-0.6)$ \\
\hline Positive for anti-Sm antibodies & $21(36.8)$ & $2(8)$ & 0.007 & NS & - \\
\hline Low C3 level & $40 / 56(71.4) 9$ & $9(36)$ & 0.003 & ND & - \\
\hline SELENA-SLEDAI score, median (range)\# & $10(4-36)$ & $6(4-20)$ & $<0.001$ & ND & - \\
\hline SELENA-SLEDAI score $\geq 8 \#$ & $43(75.4)$ & $7(28)$ & $<0.001$ & 0.046 & $0.3(0.1-0.9)$ \\
\hline Flare\# & $54(94.7)$ & $19(76)$ & 0.012 & ND & - \\
\hline Active cutaneous lupus & $30(52.6)$ & $6(24)$ & 0.016 & NS & - \\
\hline Active serositis & $13(22.8)$ & $4(16)$ & 0.48 & - & - \\
\hline Active arthritis & $29(50.8)$ & $15(60)$ & 0.45 & - & - \\
\hline $\begin{array}{l}\text { Active arthritis (no other organ } \\
\text { involvement) }\end{array}$ & $7(12.2)$ & $10(40)$ & 0.004 & 0.034 & $5.5(1.1-26.4)$ \\
\hline Active nephropathy & $16(28.1)$ & $4(16)$ & 0.24 & - & - \\
\hline Active neuropsychiatric lupus & $5(8.8)$ & $1(4)$ & 0.44 & - & - \\
\hline
\end{tabular}

* Except where indicated otherwise, values are the number (\%). Systemic lupus erythematosus (SLE) was defined as active based on a Safety of Estrogens in Lupus Erythematosus National Assessment (SELENA) version of the Systemic Lupus Erythematosus Disease Activity Index (SLEDAI) score of $\geq 4$. ELISA = enzyme-linked immunosorbent assay; OR = odds ratio; $95 \% \mathrm{Cl}=95 \% \mathrm{confi}-$ dence interval; NS = not significant; ND = not done.

$\dagger$ Bivariable analysis (Mann-Whitney $U$ test for continuous variables and chi-square test for categorical variables).

$\ddagger$ Multivariable analysis (stepwise logistic regression model with $P$ for entry $=0.3$ and $P$ for exit $=0.1$ ). Using bivariable analysis, Iow C3 level, SELENA-SLEDAI score, SELENA-SLEDAI score of $\geq 8$, and flare were associated with the detection of IFNa. These 4 items were clearly linked and interdependent. We therefore chose to include in the multivariable analysis only the items that seemed the most relevant and the most significant in bivariable analysis (i.e., SELENA-SLEDAI score $\geq 8$ ).

$\S$ Excluding antimalarials and prednisone.

I Value shown is the number of positive assay results/number of patients assessed (\%).

\# Defined using the SELENA flare instrument.

activity in SLE (4-7). Indeed, anti-DNA antibody positivity is associated with overall SLE activity and can be useful in monitoring that activity. However, the sensitivity and specificity of that association are relatively low, both $~ 66 \%(6)$, which is in good accordance with our results. Clearly, some SLE populations have persistently elevated anti-DNA antibody titers but not active disease $(54,55)$. The latter observation implies that positivity for anti-DNA antibodies will have limited impact on the pretest likelihood of active disease for a given SLE patient (6). That discordance might be overcome by using the IFNa digital ELISA, which has better specificity, likelihood ratio for positive results, and positive predictive value to identify active disease and a flare than the Farr assay. Importantly, the bioassay-assessed serum IFNa level, already used routinely in our institution, was also a better biomarker of disease activity than the Farr assay. However, the ability of the digital ELISA to detect low-abnormal serum IFNa concentrations and low disease activity was more sensitive than the bioassay. Furthermore, it is important to note that bioassays based on IFNa antiviral properties are difficult to standardize, which could limit the generalization of the data presented in this study.

Considering the unprecedented number of new agents being developed to treat SLE via targeting of IFN signaling, having an ultrasensitive, valid, easy-to-use, and standardized assay to directly assess IFNa expression in SLE patients will certainly help guide physicians' treatment choices. Whether the direct IFNa determination can be used to predict an SLE flare in the ensuing weeks after assessment remains to be tested. IFN scores have been dis- 
appointing for that purpose, with several studies showing a lack of association between the IFN signature and longitudinal disease activity changes or risk of SLE flare $(34,56)$. Despite that lack of association, the possibility that IFNa-related biomarkers could predict future flares was highlighted by the monitoring of IFN-regulated chemokine levels in SLE patients (24). In that study, serum levels of CXCL10, CCL2, and CCL19 chemokines were linked with SLE activity and performed better as biomarkers than the currently available laboratory tests to predict a flare over the following year (24). However, monitoring of those 3 chemokines remains difficult in routine practice. We are currently studying the abilities of the IFNa digital ELISA and bioassay to predict a lupus flare.

Using an ultrasensitive assay may also contribute to improving our understanding of SLE pathogenesis. Indeed, with the digital ELISA, abnormal IFNa levels were significantly associated with the presence of anti-Sm antibodies, but not with other anti-RNP antibodies tested. That finding contrasts with the bioassay analysis and other previous studies that used different cytokine dosage methods and showed abnormal IFNa levels to be associated with other anti-RNP antibodies, such as anti-RNP or anti-Ro/SSA antibodies $(29,32-34,57,58)$. Whether this new information is important in SLE pathogenesis remains to be elucidated.

Our study has certain limitations. We compared the IFNa digital ELISA measurements with the ISG score and found a highly positive correlation between the 2 parameters, suggesting that the digital assay may be used in assignment of patients to antiIFN drugs (26). According to a recent study, for some patients an ISG score could be more sensitive than a digital assay to detect low IFNa concentrations ( $<5 \mathrm{fg} / \mathrm{ml}$ ) (37). However, because our calculated threshold associated with active disease was $266 \mathrm{fg} /$ $\mathrm{ml}$, which is far above the lower limit of detection of the digital ELISA, a very low IFNa concentration might not contribute to identifying patients with clinically active SLE. Furthermore, unless the digital ELISA results are compared directly to ISG scores in a larger panel of patients, it will not be possible to determine their clinical value in patient assignment to anti-IFN treatment. Moreover, these results must be validated in other independent cohorts.

In conclusion, our data support the notion that direct serum IFNa determination with a highly sensitive, easy-to-standardize assay might be useful for clinical monitoring of SLE activity and the selection of the best candidates for anti-IFNa treatment.

\section{ACKNOWLEDGMENTS}

We thank the patients, the healthy donors, the nurses, and the Department of Internal Medicine 2 staff who participated in this study.

\section{AUTHOR CONTRIBUTIONS}

All authors were involved in drafting the article or revising it critically for important intellectual content, and all authors approved the final ver- sion to be submitted for publication. Dr. Mathian had full access to all of the data in the study and takes responsibility for the integrity of the data and the accuracy of the data analysis.

Study conception and design. Mathian, Mouries-Martin, Dorgham, Barnabei, Rozenberg, Gorochov, Amoura.

Acquisition of data. Mathian, Mouries-Martin, Dorgham, Barnabei, Ben Salah, Cohen-Aubart, Garrido Castillo, Haroche, Hie, Pineton de Chambrun, Miyara, Sterlin, Pha, Lê Thi Huong, Rieux-Laucat, Rozenberg.

Analysis and interpretation of data. Mathian, Mouries-Martin, Dorgham, Devilliers, Barnabei, Pineton de Chambrun, Rozenberg, Gorochov, Amoura.

\section{REFERENCES}

1. Tsokos GC. Systemic lupus erythematosus. N Engl J Med 2011;365: 2110-21.

2. Lisnevskaia L, Murphy G, Isenberg D. Systemic lupus erythematosus. Lancet 2014;384:1878-88.

3. Tektonidou MG, Lewandowski LB, Hu J, Dasgupta A, Ward MM. Survival in adults and children with systemic lupus erythematosus: a systematic review and Bayesian meta-analysis of studies from 1950 to 2016. Ann Rheum Dis 2017;76:2009-16.

4. Agmon-Levin N, Damoiseaux J, Kallenberg C, Sack U, Witte T, Herold $\mathrm{M}$, et al. International recommendations for the assessment of autoantibodies to cellular antigens referred to as antinuclear antibodies. Ann Rheum Dis 2014;73:17-23.

5. Neogi T, Gladman DD, Ibanez D, Urowitz M. Anti-dsDNA antibody testing by Farr and ELISA techniques is not equivalent. J Rheumatol 2006;33:1785-8.

6. Kavanaugh AF, Solomon DH. Guidelines for immunologic laboratory testing in the rheumatic diseases: anti-DNA antibody tests. Arthritis Rheum 2002;47:546-55.

7. Sherer Y, Gorstein A, Fritzler MJ, Shoenfeld Y. Autoantibody explosion in systemic lupus erythematosus: more than 100 different antibodies found in SLE patients. Semin Arthritis Rheum 2004;34:501-37.

8. Theofilopoulos AN, Baccala R, Beutler B, Kono DH. Type I interferons $(\alpha / \beta)$ in immunity and autoimmunity. Annu Rev Immunol 2005;23:307-36.

9. Obermoser $\mathrm{G}$, Pascual V. The interferon- $a$ signature of systemic lupus erythematosus. Lupus 2010;19:1012-9.

10. Ronnblom L, Elkon KB. Cytokines as therapeutic targets in SLE. Nat Rev Rheumatol 2010;6:339-47.

11. Niewold TB. Interferon a as a primary pathogenic factor in human lupus. J Interferon Cytokine Res 2011;31:887-92.

12. Ronnblom L, Alm GV, Eloranta ML. The type I interferon system in the development of lupus. Semin Immunol 2011;23:113-21.

13. Lauwerys BR, Ducreux J, Houssiau FA. Type I interferon blockade in systemic lupus erythematosus: where do we stand? Rheumatology (Oxford) 2014;53:1369-76.

14. Kirou KA, Gkrouzman E. Anti-interferon a treatment in SLE. Clin Immunol 2013;148:303-12.

15. Hooks JJ, Moutsopoulos HM, Geis SA, Stahl NI, Decker JL, Notkins AL, et al. Immune interferon in the circulation of patients with autoimmune disease. N Engl J Med 1979;301:5-8.

16. Preble OT, Black RJ, Friedman RM, Klippel JH, Vilcek J. Systemic lupus erythematosus: presence in human serum of an unusual acid-labile leukocyte interferon. Science 1982;216:429-31.

17. Ytterberg SR, Schnitzer TJ. Serum interferon levels in patients with systemic lupus erythematosus. Arthritis Rheum 1982;25:401-6.

18. Bennett L, Palucka AK, Arce E, Cantrell V, Borvak J, Banchereau $\mathrm{J}$, et al. Interferon and granulopoiesis signatures in systemic lupus erythematosus blood. J Exp Med 2003;197:711-23. 
19. Baechler EC, Batliwalla FM, Karypis G, Gaffney PM, Ortmann WA, Espe KJ, et al. Interferon-inducible gene expression signature in peripheral blood cells of patients with severe lupus. Proc Natl Acad Sci U S A 2003;100:2610-5.

20. Chiche L, Jourde-Chiche N, Whalen E, Presnell S, Gersuk V, Dang $\mathrm{K}$, et al. Modular transcriptional repertoire analyses of adults with systemic lupus erythematosus reveal distinct type I and type II interferon signatures. Arthritis Rheumatol 2014;66:1583-95.

21. Kanayama Y, Kim T, Inariba H, Negoro N, Okamura M, Takeda T, et al. Possible involvement of interferon $\alpha$ in the pathogenesis of fever in systemic lupus erythematosus. Ann Rheum Dis 1989;48:861-3.

22. Bengtsson AA, Sturfelt G, Truedsson L, Blomberg J, Alm G, Vallin $\mathrm{H}$, et al. Activation of type I interferon system in systemic lupus erythematosus correlates with disease activity but not with antiretroviral antibodies. Lupus 2000;9:664-71.

23. Dall'Era MC, Cardarelli PM, Preston BT, Witte A, Davis JC Jr. Type I interferon correlates with serological and clinical manifestations of SLE. Ann Rheum Dis 2005;64:1692-7.

24. Bauer JW, Petri M, Batliwalla FM, Koeuth T, Wilson J, Slattery C, et al. Interferon-regulated chemokines as biomarkers of systemic lupus erythematosus disease activity: a validation study. Arthritis Rheum 2009;60:3098-107.

25. Rose T, Grutzkau A, Klotsche J, Enghard P, Flechsig A, Keller J, et al. Are interferon-related biomarkers advantageous for monitoring disease activity in systemic lupus erythematosus? A longitudinal benchmark study. Rheumatology (Oxford) 2017;56:1618-26.

26. Khamashta M, Merrill JT, Werth VP, Furie R, Kalunian K, Illei GG, et al. Sifalimumab, an anti-interferon-a monoclonal antibody, in moderate to severe systemic lupus erythematosus: a randomised, double-blind, placebo-controlled study. Ann Rheum Dis 2016;75:1909-16.

27. Furie R, Khamashta M, Merrill JT, Werth VP, Kalunian K, Brohawn $P$, et al. Anifrolumab, an anti-interferon-a receptor monoclonal antibody, in moderate-to-severe systemic lupus erythematosus. Arthritis Rheumatol 2017;69:376-86.

28. Jabs WJ, Hennig C, Zawatzky R, Kirchner H. Failure to detect antiviral activity in serum and plasma of healthy individuals displaying high activity in ELISA for IFN- $\alpha$ and IFN- $\beta$. J Interferon Cytokine Res 1999;19:463-9.

29. Feng X, Wu H, Grossman JM, Hanvivadhanakul P, FitzGerald JD, Park GS, et al. Association of increased interferon-inducible gene expression with disease activity and lupus nephritis in patients with systemic lupus erythematosus. Arthritis Rheum 2006;54:295162.

30. Yao Y, Higgs BW, Morehouse C, de Los Reyes M, Trigona W, Brohawn $\mathrm{P}$, et al. Development of potential pharmacodynamic and diagnostic markers for anti-IFN-a monoclonal antibody trials in systemic lupus erythematosus. Hum Genomics Proteomics 2009;2009:374312.

31. Yao Y, Higgs BW, Richman L, White B, Jallal B. Use of type I interferon-inducible mRNAs as pharmacodynamic markers and potential diagnostic markers in trials with sifalimumab, an antiIFNa antibody, in systemic lupus erythematosus. Arthritis Res Ther 2010;12 Suppl 1:S6.

32. Kirou KA, Lee C, George S, Louca K, Papagiannis IG, Peterson $M G$, et al. Coordinate overexpression of interferon- $a$-induced genes in systemic lupus erythematosus. Arthritis Rheum 2004;50:3958-67.

33. Kirou KA, Lee C, George S, Louca K, Peterson MG, Crow MK. Activation of the interferon-a pathway identifies a subgroup of systemic lupus erythematosus patients with distinct serologic features and active disease. Arthritis Rheum 2005;52:1491503.
34. Petri M, Singh S, Tesfasyone H, Dedrick R, Fry K, Lal P, et al. Longitudinal expression of type I interferon responsive genes in systemic lupus erythematosus. Lupus 2009;18:980-9.

35. Rissin DM, Kan CW, Campbell TG, Howes SC, Fournier DR, Song $\mathrm{L}$, et al. Single-molecule enzyme-linked immunosorbent assay detects serum proteins at subfemtomolar concentrations. Nat Biotechnol 2010;28:595-9.

36. Wilson DH, Rissin DM, Kan CW, Fournier DR, Piech T, Campbell TG, et al. The simoa HD-1 analyzer: a novel fully automated digital immunoassay analyzer with single-molecule sensitivity and multiplexing. J Lab Autom 2016;21:533-47.

37. Rodero MP, Decalf J, Bondet V, Hunt D, Rice GI, Werneke S, et al. Detection of interferon a protein reveals differential levels and cellular sources in disease. J Exp Med 2017;214:1547-55.

38. Lebon P, Ponsot G, Aicardi J, Goutieres F, Arthuis M. Early intrathecal synthesis of interferon in herpes encephalitis. Biomedicine 1979;31:267-71.

39. Lebon P, Badoual J, Ponsot G, Goutieres F, Hemeury-Cukier F, Aicardi J. Intrathecal synthesis of interferon-a in infants with progressive familial encephalopathy. J Neurol Sci 1988;84:201-8.

40. Hausfater P, Fillet AM, Rozenberg F, Arthaud M, Trystram D, Huraux $\mathrm{JM}$, et al. Prevalence of viral infection markers by polymerase chain reaction amplification and interferon-a measurements among patients undergoing lumbar puncture in an emergency department. J Med Virol 2004;73:137-46.

41. Hochberg MC. Updating the American College of Rheumatology revised criteria for the classification of systemic lupus erythematosus [letter]. Arthritis Rheum 1997;40:1725.

42. Bombardier C, Gladman DD, Urowitz MB, Caron D, Chang $\mathrm{CH}$, the Committee on Prognosis Studies in SLE. Derivation of the SLEDAI: a disease activity index for lupus patients. Arthritis Rheum 1992;35:630-40.

43. Buyon JP, Petri MA, Kim MY, Kalunian KC, Grossman J, Hahn $\mathrm{BH}$, et al. The effect of combined estrogen and progesterone hormone replacement therapy on disease activity in systemic lupus erythematosus: a randomized trial. Ann Intern Med 2005;142:953-62.

44. Petri M, Kim MY, Kalunian KC, Grossman J, Hahn BH, Sammaritano $\mathrm{LR}$, et al. Combined oral contraceptives in women with systemic lupus erythematosus. N Engl J Med 2005;353:2550-8.

45. Weening JJ, D'Agati VD, Schwartz MM, Seshan SV, Alpers CE, Appel GB, et al. The classification of glomerulonephritis in systemic lupus erythematosus revisited. Kidney Int 2004;65:52130.

46. Gresser I, Bandu MT, Brouty-Boye D, Tovey M. Pronounced antiviral activity of human interferon on bovine and porcine cells. Nature 1974;251:543-5.

47. Lebon P, Commoy-Chevalier MJ, Robert-Galliot B, Morin A, Chany C. Production of human type I interferon by lymphocytes in contact with cells infected by herpes virus and fixed with glutaraldehyde. C R Seances Acad Sci D 1980;290:37-40.

48. Batteux F, Palmer P, Daeron M, Weill B, Lebon P. FCyRII (CD32)dependent induction of interferon- $\alpha$ by serum from patients with lupus erythematosus. Eur Cytokine Netw 1999;10:509-14.

49. Vezinet F, Lebon P, Amoudry C, Gibert C. Herpes encephalitis in adults and interferon. Nouv Presse Med 1981;10:1135-8.

50. Van Vollenhoven R, Voskuyl A, Bertsias G, Aranow C, Aringer M, Arnaud $L$, et al. A framework for remission in SLE: consensus findings from a large international task force on definitions of remission in SLE (DORIS). Ann Rheum Dis 2017;76:554-61.

51. DeLong ER, DeLong DM, Clarke-Pearson DL. Comparing the areas under two or more correlated receiver operating characteristic curves: a nonparametric approach. Biometrics 1988;44:837-45. 
52. Rice GI, Forte GM, Szynkiewicz M, Chase DS, Aeby A, AbdelHamid MS, et al. Assessment of interferon-related biomarkers in Aicardi-Goutieres syndrome associated with mutations in TREX1, RNASEH2A, RNASEH2B, RNASEH2C, SAMHD1, and ADAR: a case-control study. Lancet Neurol 2013;12:1159-69.

53. Rice GI, Melki I, Fremond ML, Briggs TA, Rodero MP, Kitabayashi $\mathrm{N}$, et al. Assessment of type I interferon signaling in pediatric inflammatory disease. J Clin Immunol 2017;37:123-32.

54. Gladman DD, Urowitz MB, Keystone EC. Serologically active clinically quiescent systemic lupus erythematosus: a discordance between clinical and serologic features. Am J Med 1979;66:210-5.

55. Walz LeBlanc BA, Gladman DD, Urowitz MB. Serologically active clinically quiescent systemic lupus erythematosus-predictors of clinical flares. J Rheumatol 1994;21:2239-41.
56. Landolt-Marticorena C, Bonventi G, Lubovich A, Ferguson C, Unnithan T, Su J, et al. Lack of association between the interferon-a signature and longitudinal changes in disease activity in systemic lupus erythematosus. Ann Rheum Dis 2009;68: 1440-6.

57. Weckerle CE, Franek BS, Kelly JA, Kumabe M, Mikolaitis RA, Green SL, et al. Network analysis of associations between serum interferon-a activity, autoantibodies, and clinical features in systemic lupus erythematosus. Arthritis Rheum 2011;63:104453.

58. Ko K, Franek BS, Marion M, Kaufman KM, Langefeld CD, Harley JB, et al. Genetic ancestry, serum interferon-a activity, and autoantibodies in systemic lupus erythematosus. J Rheumatol 2012;39:1238-40. 